\title{
ON THE LOWER DEVONIC AND ONTARIC FORMATIONS OF MARYLAND.
}

\author{
By Charles Schuchert, \\ Assistant Curator, Division of Stratigraphic Paleontology.
}

Cumberland, Maryland, has long been famous for its Oriskany fossils, which were first brought to the attention of paleontologists by Mr. William Andrews, and described by Hall in the third volume of the Paleontology of New York. The Helderbergian fossils are more difficult to secure, and these "Medals of Creation" become more and more rare as one proceeds downward in the section. It is for this reason, as well as for the great amount of folding and sometimes of crumpling to which the formations have been subjected, that the perfect succession of the Ontaric ${ }^{a}$ and Lower Devonic rocks of Maryland has so long remained in obscurity. In a general way that succession has been known for many years, but as late as 1897 the term Lewistown formation was used to cover the equivalents of the New York, Niagara, Salina, and Lower Helderberg. Mr. Robert H. Gordon began to collect fossils about Cumberland in 1894, and through him, in the autumn of $1899, \mathrm{my}$ own interest in this locality became so great that since then we have together gone over the sections five times. In the main our studies have been confined to the Helderbergian and Oriskanian deposits, though we have investigated the lower formations often enough to learn that the composite section (p. 422) is essentially correct. In regard to the lower beds of the Ontaric here discussed use has been made of the work of the Maryland Geological Survey, by R. B. Rowe and C. C. O'Harra.

In this connection, $\mathrm{I}$ desire to express my indebtedness to $\mathrm{Mr}$. Gordon, whose detailed knowledge of the formations around Cumberland,

a The American equivalent for Upper Silurian. For definition of this and the Lower Devonic terms here used see Clarke and Schuchert, Science, December 15, 1899, pp. 874-78. 
and whose aid and interest in my work have greatly increased the value of the present paper. The work of the local collectors of Cumberland, Messrs. Frank Hartley, George M. Perdew, and G. M. Roeder, has also been of much benefit. These united efforts have resulted in unearthing many new species and new faunulæ in which the Cystidea form an important part. The best material in the collections has been deposited in the United States National Museum, and will serve as the basis for a monograph of the Ontaric and Lower Devonic fossils of Maryland, now in preparation for the Geological Survey of that State, under the direction of Dr. W. B. Clark.

Cumberland Basin.-The Ontaric and Devonic deposits, from the Juniata to the close of the Oriskany, were laid down in an Appalachian trough, which Ulrich and Schuchert ${ }^{a}$ have termed the Cumberland Basin. This basin was bounded on the west by the Helderbergian barrier, which existed possibly from Clinton, but certainly from Niagaran time, and extended from the region of Cayuga Lake, New York, southwestward to west of Altoona, Pennsylvania, through westernmost Maryland, central West Virginia, into eastern Tennessee. To the east of this barrier and about parallel with it was the Appalachian Valley fold. - Between these lay the Cumberland Basin, which steadily subsided from early Ontaric time to the close of the Oriskanian. The area of greatest subsidence was in central Pennsylvania (Lewistown), since here occurs the greatest thickness for nearly all the formations. To the north and south the formations pinch out, but during Helderbergian time a transgression sets in which first attains the Mohawk River in New York and subsequently spreads as far south as Hancock County, Tennessee. During the Becraft of Helderbergian time, in the western area of the Cumberland Basin, throughout West Virginia, Maryland, and southern Pennsylvania, little deposition took place, but about 60 miles east conditions were normal and here occur faunas of Becraft time. This sea spread north to the Mohawk River, but south of Covington, Virginia, it had no great extent. In the western area the Lower Oriskany black chert rests conformably upon, but sharply separated from, the late New Scotland shale zone. In the eastern area nothing as yet has been found comparable with the Lower Oriskany of the Cumberland region, and it may be that no deposits of this time were there laid down. During Upper Oriskany time sedimentation was again general and continued until the close of the Maryland Oriskanian. Then a land condition prevailed in this basin south of middle Pennsylvania, throughout Esopus and Onondaga time. To the north of middle Pennsylvania, however, the Oriskanian sea continued, and finally, in late Oriskanian time (Decewville), the Atlantic fauna spread by way of the Mohawk depression into the Mississippian province. The

${ }^{a}$ Report of the New York State Paleontologist, 1901 [1902], pp. 647-652. 
Mississippian Middle Devonic transgression did not attain its greatest extent until Marcellus time, when it crossed the Helderbergian barrier and completely invaded the Cumberland Basin as far east as the Appalachian Valley fold. Then the Atlantic fauna again spread into the Marcellus sea of the Mississippian province.

Juniata, Tuscarora, and-Niagaran deposits of Cumberland Basin.In the present paper the lower members of the Ontaric will not be further described than to mention that the formations beneath the Salina have a united thickness of 1,934 feet. More detail is given in the composite section (pp. 423-4). The fauna from these formations is at present a small one, and outside of Arthrophycus harlani, Atrypa reticularis, and Leptrena rhomboidalis, all the species appear to be new. While these formations have the position of the New York Medina, Clinton, Rochester, Lockport, and Guelph, they are not all to be called by these names, because, in the absence of characteristic species, the faunas indicate that the Maryland Niagaran deposits belong to another sea province. The conspicuous life element of these sediments is represented by a few species of Ostracoda, which are at times so wonderfully prolific as to make up, in large part, limestone bands 2 to 4 inches thick. These forms appear in the so-called Clinton, attain greater development in the thin limestone bands of the following formation, and in the Salina are the essential fossils, where the small Ostracoda are joined by large Leperditia. The other fossils of the lower formations are a few species of brachiopods of the genera Rhynchonella and Rhynchospira; sometimes quite prolific, and of the trilobites Calymene, Dalmanites, and Homalonotus. This faunal development is wholly unlike that of the Niagaran of the interior United States, and is known to be restricted to the Appalachian region from southern Virginia north into New York. For this area note the absence of the following fossils characteristic of the New York Niagaran: Spirifer radiatus, S. niagarensis, S. crispus, S. sulcatus, Pentamerus oblongus, Caryocrinus, Eucalyptocrinus, etc. These facts show that the Maryland faunas were probably derived from the east or the Atlantic during Siluric time, and that this sea then had no communication with the one farther west, which Walcott has called the Mississippian sea. ${ }^{a}$

Salina formation.-Ten miles southwest of Cumberland, along the line of the Baltimore and Ohio Railroad, and a little west of the station of Pinto, Maryland, there is a splendid section of Salina rocks. Every foot of the 1,125 feet in the vertical beds of this formation, which is described in detail in the composite section, can here be studied. The Niagaran deposits are seen to pass without apparent break into the Salina, but no part of its fauna is found higher up,

a Proc. Amer. Assoc. Adv. Sci., XLII, June, 1894, pp. 129-169. 
unless it be a few of the Ostracoda which remain undetermined. The lower 400 feet of the Salina formation are characterized by Ostracoda, particularly the lowest 130 feet, or the cement beds, where these small crustaceans are often present in considerable numbers. Not a fragment of Eurypterus has been secured here.

The next 285 feet introduce a very meager fauna, a small Meristella predominating and becoming the common fossil in the higher beds. Here also has been found a single plate of the fish Palraspis bitruncata. Just above, or about 700 feet above the base of the formation, there is a well-marked, but thin, fossiliferous zone, having small Rhynchonella lamellatu in abundance, a Rhynchospira recalling $R$. globosa, a small Meristella, Orthothetes, new species; Murchisonia, a small Modiolopsis-like bivalve, and, rarely, Tentaculites gyracanthus. Above this horizon for nearly 425 feet no fossils other than the small Meristella have been found. Then a prolific fauna indicating the Manlius formation rapidly makes its appearance.

The Salina formation of Maryland is a continuous series of deposits, and appears to be the equivalent not only of all the Salina and Waterlime of New York, but also includes the hiatus between the Waterlime beds with Eurypterus and the "Bull Head" rock of western New York correlated with the Manlius. In eastern New York the whole of the Salina lies beneath the "Corralline limestone" of the Schoharie section, yet some of the diagnostic fossils of this zone occur in Maryland at the base of the next, or Manlius, formation as here defined. In New Jersey it appears that all of Weller's " Decker Ferry formation," from what he calls the "Bossardville limestone," up to the "Coralline limestone" bed of his "Rhynchonella lamellata zone," representing a thickness of 42 feet, includes the horizon either of our bed $5 a$ of the Salina formation, or part of this zone and our $4 f$ of the Manlius. It seems hardly probable that all of Weller's Decker Ferry is so young as the base of the Maryland Manlius, for if it were one would expect to find some of the cystids, especially Sphxrocystites, the leading fossil of the lower Manlius. In any event this formation is either transitional to or lies partly in our basal member of the Manlius. This correlation is further supported by a study of a number of sections extending from southern Pennsylvania into New Jersey, and thence to the type locality of Schoharie, New York. These sections will be published elsewhere.

The Salina of Maryland is continuous with that of Pennsylvania, where it attains a thickness of 1,600 feet in Perry County. Parts of it have received various names, as Bloomsburg red shale, Bridgeport sandstone (= Lower Salina), and Bloomfield or Landisburg sandstone (= Middle Salina). In Pennsylvania, as in Maryland, the formation is devoid of Eurypterus (except at Selinsgrove Junction, where were found a few thoracic segments), but it abounds in large Leperditia 
and, rarely, in Palxaspis. The Pennsylvania Salina unites the deposits of New York with those of Maryland and the Virginias.

Manlius formation. - This formation has in Maryland a thickness of about 110 feet and consists, as a rule, of thin-bedded, impure limestones, which in the lower third are more shale than limestone. It should be said in this connection that there is no natural line or lithologic difference by which the Manlius can be separated from the Salina below or from the Coeymans above. The sequence of deposition is here continuous, and there was no marked physical event in the Cumberland Basin to cause a change in the lithology at this time. Our line of separation is therefore somewhat arbitrary, and is based on the first abundant occurrence of fossils of the type of the New York Manlius, a criterion of unequal value in different places. The early abundance of life in this horizon recalls the "Coralline limestone" fauna of New York, and it soon is blended with the Bryozoa and cystid fauna found a little higher in the lower third of the Manlius.

At Pinto, Maryland, near the base of the Manlius, occurs a great abundance of Cladopora rectilineata Simpson, one of the guiding fossils for these beds. It is also found at Cash Valley, near Cumberland, at about the same zone, where occasionally are obtained Acervularia (?) inxqualis Hall, Halysites, and Chonetes jerseyensis, three of the leading fossils of the "Coralline limestone" of Schoharie, New York. At this locality Spirifer octocostatus, Nucleospira of. ventricosa, and Rhynchonella approaching $R$. campbellana are likewise found.

Near the middle of the Manlius there is a zone of hard, massive, dark blue limestone, well shown near the Market street bridge, in the city of Cumberland. It was from this place and horizon that Mr. Andrews collected some of his "Lower Helderberg" fossils, which were described as such by Hall. They are Merista typa, M. camura, Spirifer modestus, S. octocostatus, and Strophonella geniculata. None of these species are known to occur outside of the Manlius, and they must therefore be eliminated from the Helderbergian as now restricted, which begins with the next formation or Coeymans. The exact locality of the type specimen of Sphrrocystites multifasciatus is not known, but it could have been found only in the Manlius horizon about Cumberland.

In the ballast quarries of the Baltimore and Ohio Railroad, near Keyser, West Virginia, ${ }^{a}$ may be seen to good advantage an extended section not only of the Manlius and about 100 feet of the Salina, but also of the entire Coeymans and New Scotland formations. The lowest zone $(4 f)$ does not yield the corals of the "Coralline" horizon,

$a$ It is reported that this railroad had spent upward of $\$ 2,000,000$ in this quarry during the past three years. The great amount of work thus represented has made it possible to gather a rew and unique Manlius fauna.

Proc. N. M. vol. xxvi-02-29 
but the brachiopods associated with them, and mentioned above, occur here.

Zone $4 d$ is the most interesting faunally, and is marked by a great abundance of the cystid Spharocystites multifasciatus. Associated with this species, but as a rule far less abundant, occur ten new species of cystids, several new crinoids, Spirifer modestus and S. vanuxemi in profusion, Rhynchotrema formosa, and many other forms. Immediately above $(4 c)$ occur numerous fine specimens of that littleunderstood fossil Camarocrimus; also Calymene camerata and Tentaculites gyracanthus. Then comes a zone with a new form of Gypidula near $G$. galeata.

The Manlius may also be studied to advantage at the Devil's Back Bone near Cumberland. At this point the formation is less shaly, with more pure dark blue limestone, and the fauna is somewhat different because the fossils are derived from slightly different horizons than at the Keyser quarries. For the sake of completeness the Manlius part of the section is here given:

D. B. B. $a$. Thin-bedded shaly limestone abounding in Bryozoa of the genera Fenestella, Polypora, Ptilodictya, Orthopora, Drymotrypa, Stictoporina, Batostomella, and Lioclema; also Orthothetes deformis, Rhynchotrema formosa, and very rarely Sphorocystites multifasciatus . . . . . . . . . . . . . . . . . . . . . . . . . . . . 32 feet.

D. B. B. $b$. Massive hard dark blue limestone, the upper 7 feet abounding in a new form of Gypidula. Just below this horizon are found Merista typa, Spirifer modestus, S. vanuxemi, Strophonelia geniculata, Orthothetes deformis, and rarely Tentaculites gyracanthus . . . . . . . . . . . . . . . . . . . . . . . . . . . . . 26 feet.

D. B. B. c. Thin-bedded limestone with slender Bryozoa of the genus Orthopora and rarely a Camarocrinus 32 feet. About 20 feet more of the beds below are regarded as Manlius.

From this it is seen that the faunulæ of the Manlius are not constant even within so small an area as 25 miles around Cumberland. For instance, at Keyser, West Virginia, the lower third swarms with cystids, while elsewhere these fossils are very rare. At the Devil's Back Bone there is a bed 7 feet thick abounding in a Gypidula of small size. At Keyser this form is found higher up and has increased in size, while near Pinto it is found still higher and has developed into the almost typical Gypidula galeata of the Coeymans. As a rule, Stromatopora does not develop abundantly in the Manlius, and yet near Hyndman, Pennsylvania, just over the Maryland line, there is a bed 5 feet thick composed of this form (see section on p. 419). Generally, however, most of the fossils occur in a restricted zone, and the difference in the faunulæ is probably due to the greater local development of certain groups, as the Cystidea, Brachiopoda, Bryozoa, and, more rarely, Stromatopora.

Coeymans limestone. - This formation throughout Maryland is fairly constant in its lithologic aspect, being a purer, heavier bedded, and tougher limestone than the Manlius. Faunally it is, as a rule, easily recognized by the Stromatopora beds, which weather out as curly or 
nodular masses. In the vicinity of Cumberland there are two Stromatopora beds, fairly constant in their position, but at Keyser, West Virginia, they are nearly obsolete. On the other hand, at Hyndman, Pennsylvania, a few miles north of Cumberland, specimens of Stromatopora are exceedingly prolific, and to bring out this development the following section is given, based on two quarries just back of the village. The strata are nearly vertical:

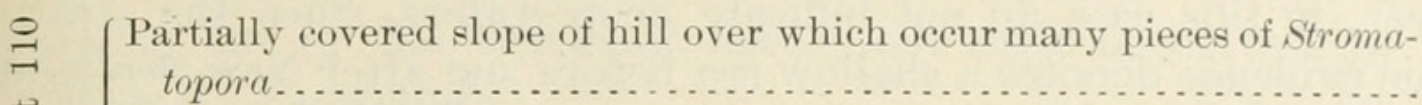
30 feet.
Upper quarry zoine ...................................... . 24 feet.
Both walls of this quarry and the intermediate limestone are filled with masses of Stromatopora of two species. Here also are found Favosites, Aulopora, Rhynchospira, etc.
Covered area . 90 feet.
Stromatopora also occurs abundantly here.

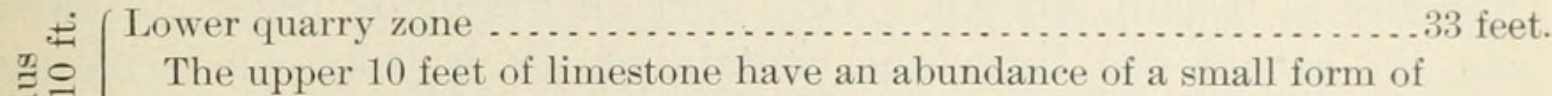 Gypidula galeata. The lower 5 feet abound in Stromatopora.
Thin-bedded limestone and shales, about The fossils are those of the cystid zone of the Keyser quarries.

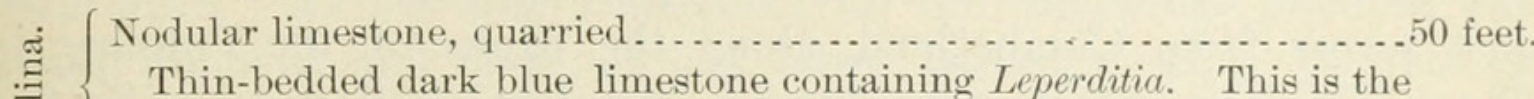 transition zone to the Salina formation.

New Scotland and Becraft limestone.-The Coeymans limestone passes without break into the New Scotland. In the upper 15 to 20 feet of the former the typical Helderbergian fauna appears, yet the diagnostic fossil Spirifer macropleura is not found here, but above, in the massive gray cherty limestone from 40 to 50 feet in thickness. This limestone is very constant in occurrence throughout western Maryland, and may be seen to best advantage in the Corrigansville quarry near Cumberland, and again at the Twenty-first Bridge of the Baltimore and Ohio Railroad, near Keyser, West Virginia.

The fossils thus far secured are those of the typical area for this horizon in Albany County, New York. Almost nothing new occurs in Maryland, but a marked difference in this fauna is the almost total absence of the prolific bryozoan development of New York.

These heavy-bedded cherty limestones gradually pass upward into shales, of which 20 feet are present in western Maryland. They, in part at least, belong with the New Scotland, since Spirifer macropleura has here been found in the lower third. Less than 60 miles to the east of Cumberland, at Cherry Run, West Virginia, the New Scotland limestone (there is no shale present) continues without break into the gray arenaceous Becraft, and here may be gathered a fauna not to be had about Cumberland. This oceurrence shows that while the Helderbergian sea was continuous east of Cumberland, west of it there may have been land conditions or possibly a shallow sea in which almost no deposits were laid down. At several localities, how- 
ever, more than 20 miles apart, this New Scotland shale horizon is always about 20 feet thick, upon which follows conformably, but with a sharp lithologic difference, the black siliceous shale of the Lower Oriskany.

A noteworthy fact connected with these shales at Twenty-first Bridge is the occurrence of manganese-phosphatic nodules, which have the general aspect of those dredged from the present deep seas. These, however, in this case do not indicate deep waters, since the stratigraphic evidence denotes a shallow sea before and after New Scotland time in the Cumberland area.

Oriskany formation.-In western Maryland, upon the shale beds of the New Scotland, and sharply separated from it, lies the black siliceous shale with a meager fauna. That collected recalls the Oriskany of Camden, Tennessee, and point to an older stage than the Oriskany as usually known. This horizon gradually passes upward into the arenaceous limestone containing the well-known Oriskany fauna. It does not, however, occur in full force until nearly 200 feet above the base of the formation, and the fauna then continues through the upper 150 feet. It is these uppermost Oriskany beds, just across from Cumberland, along the banks of the Potomac in West Virginia, which now furnish the local collectors with fine fossils. Mr. Andrews, however, secured the specimens described by Hall mainly from two quarries, now abandoned, in the city of Cumberland. One of these is on Green street, below the Episcopal Church, and the other is back of the German Lutheran Church. Both are in the upper 75 feet of the Oriskany, as in the Green street quarry the Marcellus shales plainly mark the top for measurement. However, at these quarries, and particularly in the one back of the German Lutheran Church, on Schriver's hill, the excavation was carried far below the surface into lower layers that are not shown in West Virginia. This explains why certain forms, as Spirifer cumberlandix, S. tribulis, etc., no longer, or but rarely, are found about Cumberland.

A peculiar condition of leaching of the Oriskany in this locality has made it possible to secure its fossils, completely weathered out of the inclosing rock, as siliceous pseudomorphs. This condition is restricted to Cumberland, and the reason for it will be shown presently. So many of these delicate fossils have been sent out by local collectors that it has become a general belief that they can be secured anywhere in the Oriskany of Maryland. Regarding this preservation Hall " has written:

While in the State of New York the accessible portions of the rock furnish us for the most part with casts of its fossils, or, if beyond the reach of weathering, with a compact mass of calcareous sandstone in which the fossil remains are closely 
imbedded, we find, in Maryland and some parts of Virginia, that in the friable sandstone the shells are entirely silicified and quite free from adhering stone, so that the exterior markings and internal structure are perfectly preserved; the interior being quite hollow, or filled only with loose sand. In these localities, not only do we find the cavities of large gasteropods with no more adhering matter than those of the Tertiary sands, but more unfrequently the delicate internal apparatus of the Brachiopod is almost entirely preserved.

Mr. R. B. Rowe ${ }^{a}$ was the first to explain the cause for this restricted leaching out of the Oriskany fossils and their occurrence in "sand pockets." He writes:

Most of the fine collecting grounds for Oriskany fossils in this region are within five or ten minutes walk from the hotels in Cumberland. The disintegration of the sandstone has been carried on there much more completely than at any other place, and has been due, no doubt, to the cutting of the Potomac River and Wills Creek across Knobley Mountain and Shrivers Ridge.

The constant downward percolation of the water from the Potomac River and Wills Creek, when both flowed over this part of Cumberland, has carried away the calcareous material of the Oriskany arenaceous limestone and the fossils, and has partially replaced the latter with silica. As leaching continued, all the calcareous material was finally remored and more or less large, partially empty pockets or caves were formed, filled with loose sand, in which the fossils are found at times in considerable quantity.

In western Maryland the Oriskanian is present in greatest volume, and it continues so both to the north and south along the strike of the Cumberland Appalachian folds. Eastward the lower black shale rapidly disappears, and at its most eastern outcrops the upper portion is generally much reduced in thickness and the calcareous material is usually absent. Here the Oriskany closely resembles the Tuscarora sandstone near the base of the Ontaric. The most easterly locality for the Oriskany, near the old shore line, shows a depth of only 50 feet, while but 8 miles west, at Hancock, it is 225 feet thick.

The thickness of the Oriskany is variable. On the Winchester road, at Pinto, the Upper Oriskany is almost entirely absent. At the Devils Back Bone it also is decidedly thinner than at Ridgely. These facts lend additional support to the evidence that western Maryland was a land area during Onondaga time, when the Oriskany formation was locally considerably removed.

The small Lower Oriskany fauna thus far collected is nearly all new, and the Upper Oriskany, also, has yielded a number of new forms since Mr. Andrews made his collection.

a The Paleodevonic formations of Maryland, a study of their stratigraphy and faunas. A dissertation presented to the board of University Studies of the Johns Hopkins University for the degree of Doctor of Philosophy, May, 1900. This thesis will be published by the Geological Survey of Maryland in the volume devoted to the Devonic formations. 
COMPOSITE SECTIOA OF THE LOWER DEVONIC AND ONTARIC OF MARYLAND.

The Marcellus stage of the Middle Devonic rests directly upon the eroded Oriskanian. No Esopus, Schoharie, or Onondaga deposits occur in Maryland or farther south.

\begin{tabular}{|c|c|c|}
\hline $\begin{array}{l}\text { Correla- } \\
\text { tions with } \\
\text { New } \\
\text { York. }\end{array}$ & $\begin{array}{l}\text { Locality } \\
\text { for } \\
\text { sections. }\end{array}$ & DESCRIPTIONS OF HORIZONS. \\
\hline 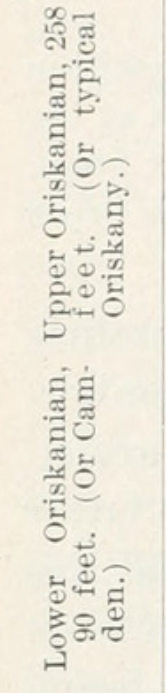 & 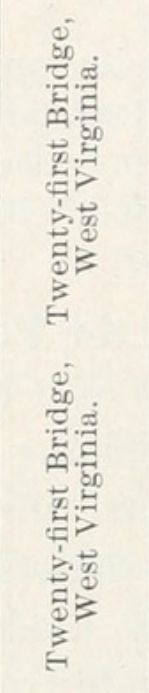 & 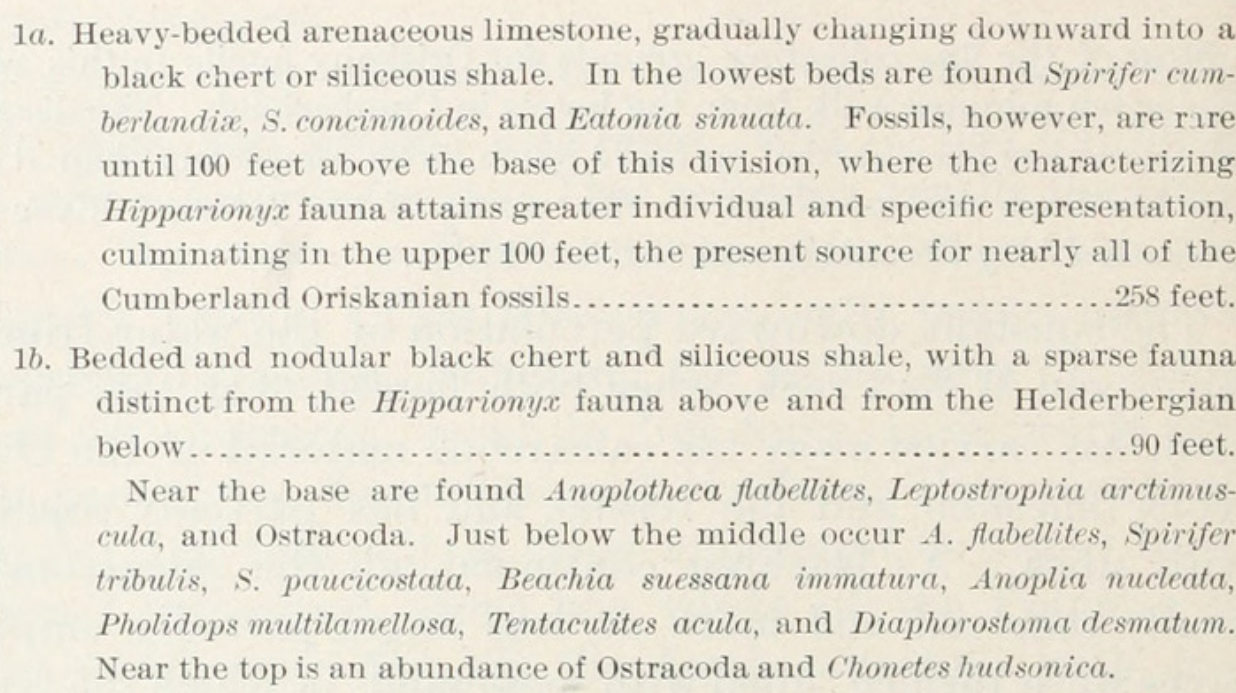 \\
\hline & & $\begin{array}{l}\text { (In western Maryland the Becraft is not present or is not normally } \\
\text { developed. Ninety miles east occur the following beds, completing the } \\
\text { interval:) }\end{array}$ \\
\hline
\end{tabular}

\begin{tabular}{l|l|l} 
& 2a. Dark blue arenaceous limestone, with lumps of black chert. The fauna is \\
& most abundant in the upper half, where Rensselæria xquiradiata is the \\
& characteristie fossil. No Spirifer macropleura occur here.... about 85 feet.
\end{tabular}

(The remainder of the section is complete in western Maryland.)

$2 b$. Soft, bluish argillaceous shales, with some harder layers and occasional manganese-phosphatic nodules; Chonetes helderbergix Rowe, Meristella arcuata, Trematospira multistriata, Spirifer macropleura, Orthothetes woolworthanus, Stropheodonta becki, ete ......................... 20 feet.

2c. Massive gray limestone, with bands of chert, becoming thin-bedded above, with partings of shale; characterized by Spirifer macropleura . . ....44 feet. The fauna can be collected to better advantage around cumberland. Some of the species are Edriocrinus pocilliformis, Dalmanella perelegans, Rhipidomella oblata, Eatonia singularis, E. peculiaris, E. medialis, Anoplotheca concava, Trematospira multistriata, Parazyga deweyi, Spirifer perlamellosus, S. macropleura, S. cyclopterus, Platyceras spirale, Phacops logani, etc.

$3 a$. Massive, regularly bedded, blue-gray limestone. It is the prominent ridge of the "Devils Back Bone," near Cumberland. At the top are found typical Gypidula galeata, Spirifer cyclopterus, and stems of Lepadocri-

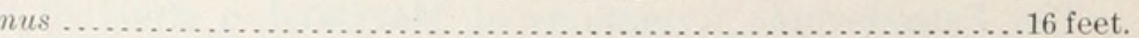

$3 b$. Shaly limestone without fossils ........................ foot 6 inches. $3 c$. Massive, regularly bedded, biue-gray, unfossiliferous limestone .....22 feet. $3 d$. Heavy-bedded nodular limestone, filled with Stromatopora (locally known as the first Stromatopora bed) $\ldots \ldots \ldots \ldots \ldots \ldots \ldots \ldots \ldots \ldots \ldots \ldots \ldots \ldots \ldots \ldots \ldots$ feet 6 inches. 3e. Heavy-bedded blue limestone, 'almost without Stromatopora.........25 feet. 
Composite section-Continued.

\begin{tabular}{|c|c|c|}
\hline $\begin{array}{l}\text { Correla- } \\
\text { tions with } \\
\text { New } \\
\text { York. }\end{array}$ & $\begin{array}{l}\text { Locality } \\
\text { for } \\
\text { sections. }\end{array}$ & DESCRIPTIONS OF HORIZONS. \\
\hline 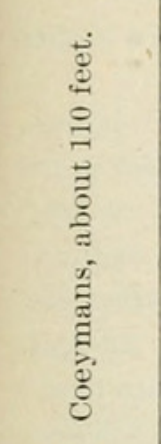 & 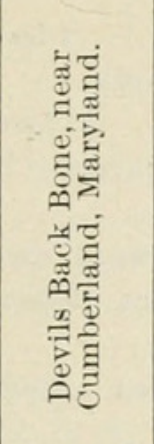 & $\begin{array}{l}\text { 3f. Second Stromatopora bed, abounding in a few species of corals........9 feet. } \\
\text { (At Keyser at about this zone oceur vast numbers of Tentaculites gyracan- } \\
\text { thus.) } \\
3 g \text {. Thin-bedded nodular limestone, with occasional Stromatopora......10 feet. } \\
3 h \text {. Heavy-bedded grayish limestone, with layers of chert more prominent above } \\
\text { and below. Fossils rare, Atrypa reticularis and } L \text {. rhomboidalis. } \\
\text { (It is probable that a part of this zone is represented in } 4 a \text { of the next } \\
\text { section, near Keyser, West Virginia.) } \\
\text { Base of Devonic. }\end{array}$ \\
\hline
\end{tabular}

Top of Ontaric. No break in deposition.

4a. Heavy-bedded solid blue limestone. No fossils seen........34 feet 6 inches

4b. A solid blue limestone, filled with a small form of Gypidula near $G$.

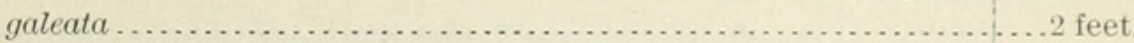

4c. Heavy-bedded impure limestone, with an abundance of Camarocrinus and more rarely Tentaculites gyracanthus, Calymene camerata, and a new species

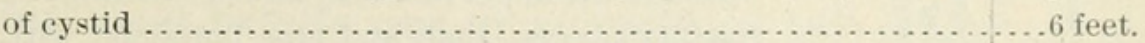

$4 d$. Thin-bedded shaly limestone and shale deeply weathered. Throughout this zone Sphærocystites multifasciatus abounds in great numbers with Spirifer modestus, Rhynchonella formosa, etc....................... 4e. A solid blue limestone ...............................

4f. Thin-bedded shaly limestone like $4 d$. Toward the base occur Nucleospira, Rhynchonella like campbellana, and Spirifer octocostatus...28 feet 6 inches.

(The upper part of the following or Pinto section terminates at the Winchester road, where the lowest Manlius abounds in Cladopora rectilineata, Favosites helderbergix præcedens, and the brachiopods just mentioned.)

$5 a$. Massive light-gray limestone, becoming more and more nodular toward the top. The only fossil seen is a bryozoan, Cyphotrypa, new species...95 feet.

$5 b$. At base, thin-bedded gray limestone, changing to shales in the upper half; fossils obscure, almost absent............................... 210 feet. $5 c$. Thin-bedded dark-blue limestone. Toward the base occur rarely Tentaculites gyracanthus; more commonly Orthothetes, new species, Rhynchonella lamellata, small Meristella, Rhynchospira, Murchisonia, and ostracods of the genera Bollia (near B. clarkei of the Niagara) and Klodenia.......135 feet.

$5 d$. Thin-bedded dark-blue limestone, with occasional papery shales; small Meristella and Leperditia. A single plate of Palraspis bitruncata was found

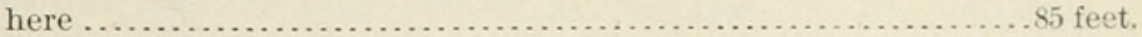

5e. Thin-bedded ribbon limestone weathering into pinnacles; small Meristella and Leperditia like alta common ...............................200 feet.

5f. Thin-bedded, somewhat crumpled, dark-blue shales with thin bands of limestone ........................................ $5 \mathrm{~g}$. Calcareous shales, dark blue in color, with thin bands of limestone, dolomite, and occasional sandstones; Leperditia . ...................200 feet.

$5 h$. Fourth cement rock; Leperditia common........................ 15 feet. $5 i$. Blue-gray shales, with thin arenaceous and calcareous layers........16 feet. $5 j$. Third cement rock ........................................... $5 k$. Greenish shales with some calcareous and arenaceous layers; Ostracoda.

5l. Second cement rock; Leperditia and Bollia........................ 18 feet.

$5 \mathrm{~m}$. Massive magnesian limestone toward the top, with beds of shale toward the bottom; Ostracoda...................................... 5n. First cement rock; Bollia, Beyrichia, and Leperditia.................9 feet. 5o. Greenish-gray and mottled dark-brown and olive sandstones. .3 feet 6 inches. 5 p. Disintegrated yellow rock. First occurrence in this section of Leperditia, which is abundant along with Bollia near B. clarkei and Octonaria. 8 feet. 
Composite section-Continued.

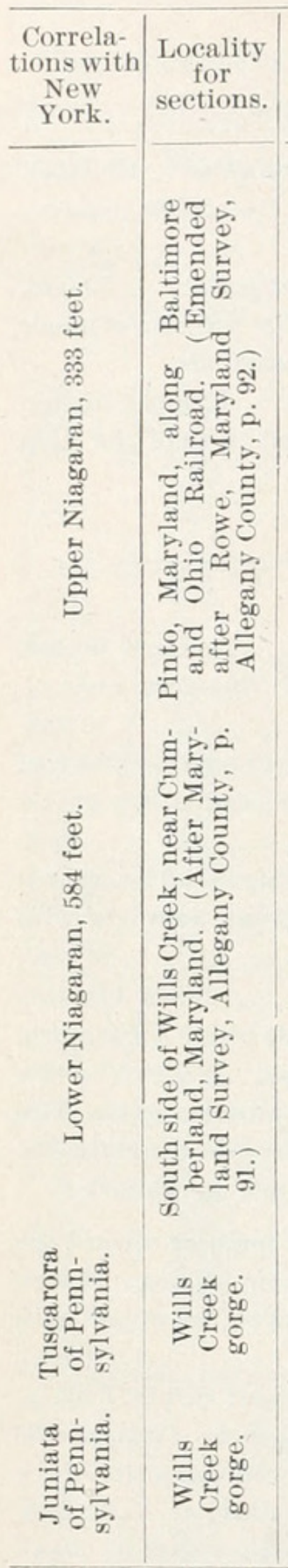

DESCRIPTIONS OF HORIZONS.

6a. Thin-bedded sandstones

.2 feet 6 inches

6b. Grayish-black shales abounding in poorly preserved Bryozoa.

13 feet 6 inches.

6c. Black shales, with thin bands of sandstone and some layers of limestone; Ostracoda abundant........................................

6d. Thin-bedded dark-blue limestone; fossils common toward the bottom; Ostracoda in great profusion, Rhynchonella, Rhynchospira, Tentaculites, ete.

225 feet.

6e. Dark-blue limestone with thin shale partings; much folded. (Spring here.) Thickness estimated .70 feet.

(The Pinto section continues exposed for 159 feet lower. The remainder of the section is again taken up 10 miles east, at Wills Creek, near Cumberland, and is supposed to include the above-mentioned 159 feet of the Pinto section.)

7a. Shales and fossiliferous limestone, mostly concealed ................3 feet. 7b. Reddish shale, with a few thin limestone bands (concealed in part; may contain the upper iron-ore band of 6 inches) ..................

7c. Fossiliferous gray shale and blue limestone, with $5 \frac{1}{2}$ feet of shaly sandstone

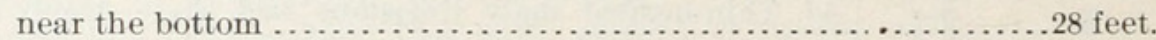

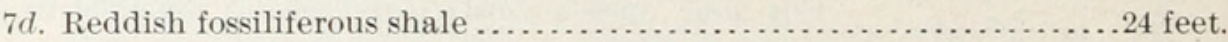

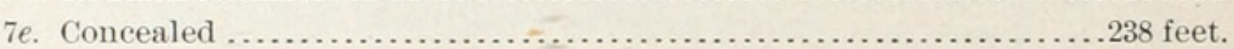

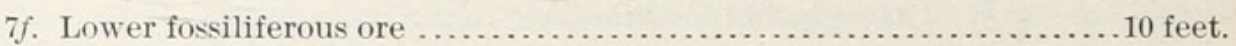

$7 g$. Rusty olive shale ...............................................

$7 h$. Fossiliferous olive-colored shale ................................ 85 feet.

$7 i$. Rusty shales above, followed by gray sandstone interstratified with olive shales ....................................................... feet.

$7 j$. Olive-colored shales, with thin beds of brownish-gray quartzite $\ldots \ldots 27$ feet.

8. Snow-white to light-gray quartzite, in places a fine conglomerate; Arthrophycus harlani, the only fossil................................

9. Interbedded dull red sandstones and shales. In Wills Creek gorge 530 feet can be seen, but the total thickness, on the basis of that in Bedford County, Pennsylvania, is probably not less than 730 feet.

"Hudson River shales." 


\section{$2 \mathrm{BHL}$ Biodiversity Heritage Library}

Schuchert, Charles. 1903. "On the lower Devonic and Ontaric formations of Maryland." Proceedings of the United States National Museum 26(1313), 413-424. https://doi.org/10.5479/si.00963801.1313.413.

View This Item Online: https://www.biodiversitylibrary.org/item/32571

DOI: https://doi.org/10.5479/si.00963801.1313.413

Permalink: https://www.biodiversitylibrary.org/partpdf/9430

\section{Holding Institution}

Smithsonian Libraries

\section{Sponsored by}

Smithsonian

\section{Copyright \& Reuse}

Copyright Status: NOT_IN_COPYRIGHT

This document was created from content at the Biodiversity Heritage Library, the world's largest open access digital library for biodiversity literature and archives. Visit BHL at https://www.biodiversitylibrary.org. 